\title{
INTEGRATING GEOMETRY INFORMATION IN THE Bid Generation of Die Casting Moulds
}

\author{
DENKENA, B. \& SCHUERMEYER, J.
}

Abstract: An analysis in the tool and mould making sector showed that methods insufficiently support the manufacturers of die casting moulds in the bid generation process. The primary aim of bid generation is to generate many first-class bids in order to gain a high quantity of profitable orders. For this purpose companies have to achieve a high calculation precision with low expenditure. In addition, a comprehensible calculation is of great importance in order to enable an internal and external comparability and analysis as well as to permit the customer to assess the performance offered. In order to support companies of the tool and mould making industry concerning these matters, a working group from industry and science analyzed the bid generation of manufacturers of die casting moulds. The article discusses the results of this analysis and describes the development of a rule-based calculation approach using geometry information of the casting part in order to calculate manufacturing costs of die casting moulds.

Key words: production, prototyping, bid, calculation, costs
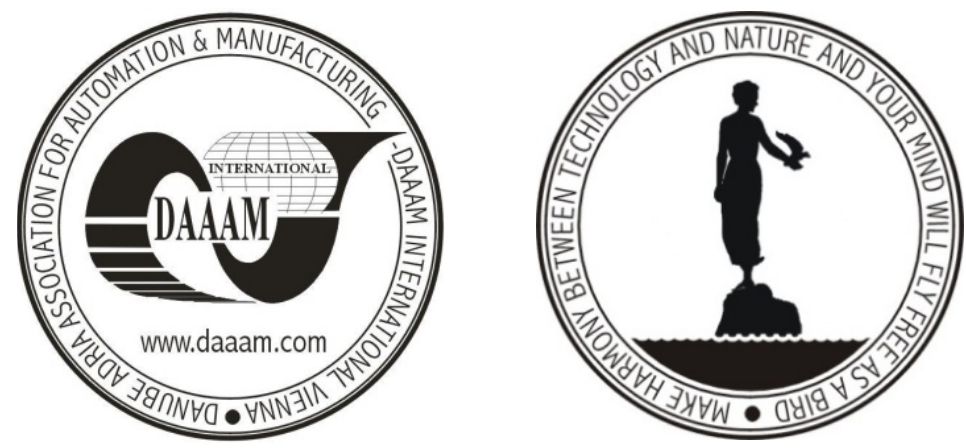

Authors' data: Prof. Dr.-Ing. Denkena, B[erend]; Dipl.-Wirtsch.-Ing. Schuermeyer, J[an], Institute of Production Engineering and Machine Tools Leibniz Universität Hannover, An der Universität 2, D-30823, Garbsen, Germany, denkena@ifw.uni-hannover.de, schuermeyer@ifw.uni-hannover.de

This Publication has to be referred as: Denkena, B[erend] \& Schuermeyer, J[an] (2009). Integrating Geometry Information in the Bid Generation of Die Casting Moulds, Chapter 61 in DAAAM International Scientific Book 2009, pp. 629-642, B. Katalinic (Ed.), Published by DAAAM International, ISBN 978-3-901509-69-8, ISSN 1726-9687, Vienna, Austria

DOI: $10.2507 /$ daaam.scibook.2009.61 